\title{
Low trophic niche overlap among trap-nesting bee species (Hymenoptera: Anthophila) in a semideciduous forest fragment
}

\author{
Léo Correia da Rocha Filho, Diego Moure-Oliveira, Carlos Alberto Garófalo \\ Departamento de Biologia, Faculdade de Filosofia, Ciências e Letras de Ribeirão Preto-FFCLRP, Universidade de São \\ Paulo-USP, Ribeirão Preto, São Paulo 14040-901, Brazil
}

Received 15 February 2018 - Revised 8 June 2018 - Accepted 7 August 2018

\begin{abstract}
Bees are important components of mutualistic interactions with plants, playing a key role as pollinators of both wild and crop plants. In this context, studies on the plants visited by bees are important to determining conservation strategies. We investigated the use of floral resources by the trap-nesting bee species sampled in a semideciduous forest fragment. Trap nests were set in the forest fragment in three different zones: forest edge, $250 \mathrm{~m}$ away from the edge and $500 \mathrm{~m}$ away from the forest edge. Pollen analysis of the residual pollen content removed from the nests of 12 bee species revealed a total of 63 pollen types from 16 botanical families. The bee community showed specialized populations with no overlap in diet. Within the community, the diet overlap was higher in closely related species, the two Tetrapedia species and the two Centris (Heterocentris) species, than in the other sampled species. Although the studied bee community is composed of widespread bee species, our data showed a low niche overlap among them, suggesting the occurrence of food niche partitioning at our study site. The asymmetry in the period of nesting activities and floral preferences among the bee species are factors that might have contributed to the low niche overlap observed.
\end{abstract}

cavity-nesting bees / diet breadth / floral oil / nectar / pollen / specialized populations

\section{INTRODUCTION}

Biotic pollination is considered one of the most important ecosystem services (Ollerton et al. 2011), and bees are well documented as keystone pollinators of both wild plants and crops (Bawa 1990; Klein et al. 2007; Potts et al. 2010; Garibaldi et al. 2013). These insects depend on floral resources for nourishment; adults visit flowers to consume nectar whereas pollen, nectar, and in some cases, floral oils are collected and

Electronic supplementary material The online version of this article (https://doi.org/10.1007/s13592-018-0599-6) contains supplementary material, which is available to authorized users.

Corresponding author: L. Rocha Filho, correiadarocha@yahoo.com.br Manuscript editor: Alexandra Klein stored in brood cells to feed their offspring (Michener 2007). As bees are effective pollinators and important components of mutualistic interactions with plants (Ballantyne et al. 2017), alterations in bee assemblages resulting from fragmentation and land-use changes could compromise not only the plant species composition but also the whole ecosystem (Potts et al. 2010). Hence, studies on the plants visited by bees and their interactions are important to the implementation of conservation strategies, and especially for understanding the potential effects of pollinator decline (Aguiar et al. 2013).

Niche breadth is an important ecological feature that is often measured by considering the degree of diet specialization (Bommarco et al. 2010). Among the different niche components, a trophic dimension is essential since all organisms must acquire and assimilate resources for 
maintenance, growth, and reproduction (Winemiller et al. 2015). Diet breadth and species' foraging behavior have been demonstrated to exert a strong influence on food networks (Beckerman et al. 2006).

In different ecosystems worldwide, most of the data on trophic niches of bees were obtained by collecting bee specimens on flowers (Dupont et al. 2003; Alarcón et al. 2008; Kratochwil et al. 2009; Santos et al. 2010; Andena et al. 2012; Chacoff et al. 2012; Aguiar et al. 2013, 2017; Aidar et al. 2015; Carman and Jenkins 2016; Ballantyne et al. 2017) or removing the pollen grains/loads from bee individuals (Lopezaraiza-Mikel et al. 2007; Bartomeus et al. 2008; Bosch et al. 2009; Vilhena et al. 2012; Hilgert-Moreira et al. 2013). However, only a few studies have investigated the trophic niches of cavity-nesting bees using residual pollen content from their nests (Quiróz-Garcia et al. 2001; Dorado et al. 2011; Rabelo et al. 2014). This methodology can be very useful when studying wild bees and their floral sources since bee individuals may visit flowers inaccessible to or outside the areas accessible to researchers (Wood et al. 2016), thus enabling the access of data on the floral resources gathered and used by female bees in brood provisioning.

Cavity-nesting bees consist of an important guild of solitary species in which females nest in preexiting cavities in dead wood, twigs, and branches or within hollow stems (Krombein 1967). Some Neotropical species such as Centris analis (Fabricius), Centris tarsata Smith, and Xylocopa frontalis (Olivier) (Apidae) have been intensively studied and suggested as potentially manageable pollinators of different crop species (Freitas and Paxton 1998; Oliveira and Schlindwein 2009; Junqueira et al. 2012). The study of the trophic niche of those bee species is an important tool to be used in management programs and the conservation of natural areas in the vicinity of crops pollinated by them.

The Caetetus Ecological Station (CES) is a large semideciduous Atlantic forest fragment located in southeastern Brazil, but the areas on its periphery are dominated by pastures and crops, especially the coffee tree, Coffea arabica L. (Rubiaceae) (Tabanez et al. 2005). Exotic plants such as the mass-flowering coffee tree can compete with native plant species for resources and contribute to a decrease in the diversity of pollinators within an area (Zuefle et al. 2008). Nonetheless, a study conducted in that Ecological Station on the community of cavity-nesting bees and wasps revealed a high diversity of species (Rocha-Filho et al. 2017) in spite of the threatened conservation status of that forest fragment (Tabanez et al. 2005). In light of the above, we aimed to study the use of floral resources by the trap-nesting bee species sampled in that forest fragment. Considering that previous studies on trophic niches of bees in different ecosystems in the Neotropics have repeatedly found low niche overlap (Aguiar et al. 2013, 2017; Rabelo et al. 2014), we hypothesized that the trap-nesting bee community sampled in the CES would be characterized by a low trophic niche overlap among the species. Additionally, we investigated if the massflowering of coffee trees located on a plantation in front of the forest fragment would be more attractive to bees than the blooms of native plant species.

\section{MATERIALS AND METHODS}

\subsection{Study site}

The study was carried out from August 2011 to July 2012 at the Caetetus Ecological Station $\left(22.4167^{\circ} \mathrm{S}, 49.7167^{\circ} \mathrm{W}\right)$, which is located in the Midwestern region of São Paulo State, Brazil (Tabanez et al. 2005). The station has a total area of 2176.1 ha that consists of native, wellpreserved forests, predominantly seasonal semideciduous forests, and agricultural lands on its surroundings, which include pastures and coffee and rubber tree [Hevea brasiliensis L. (Euphorbiaceae)] cropland (Tabanez et al. 2005). The forest fragment presents high plant species richness and complex structure and an advanced stage of succession (Saito et al. 2004). Nevertheless, its edge is characterized by a high concentration of invasive lianas and grasses (Melo et al. 2007).

The climate in that region is classified as mesothermal with dry winters and rainy summers, and annual rainfall oscillates from 1100 to $1700 \mathrm{~mm}$ (Tabanez et al. 2005). In this study, sampling during the cold/dry season took place 
in August and September in 2011 and from April to July in 2012 whereas sampling during the hot/ wet season took place from October 2011 to March 2012.

\subsection{Trap nests}

The trap nests used herein followed two models described by Camillo et al. (1995). One model was a tube made of black cardboard that is closed with a small rounded piece of the same cardboard material at one end. The tubes were $5.8 \mathrm{~cm}$ in length and $0.6 \mathrm{~cm}$ in diameter. The other $\mathrm{TN}$ model consisted of internodes of common bamboo [Bambusa vulgaris Schrad. ex J.C. Wendl. (Poaceae)] (up to $20 \mathrm{~cm}$ long, ca $0.5-2 \mathrm{~cm}$ in diameter) with one of the endings closed by a node. The cardboard tubes were inserted into horizontal holes drilled into wooden plates (55 holes each) while the bamboo internodes were arranged in bundles of 20 units into PVC tubes. The TN sets were placed in iron supports fixed within the soil and covered with plastic tiles (hereafter referred to as the "sampling station"). Three sampling stations (A, B, and C) were installed at the edge of the forest fragment and facing a coffee plantation (ca $10 \mathrm{~m}$ away from the coffee crop). Other three stations (D, E, and F) were placed within the forest, $250 \mathrm{~m}$ away from the forest edge, while other three stations $(\mathrm{G}, \mathrm{H}$, and $\mathrm{J})$ were located $500 \mathrm{~m}$ away from the edge. Coffee trees were not detected in any of both areas within the forest fragment. The sampling stations were $5 \mathrm{~m}$ away from each other. As the estimated flight range of several bee species is around $500 \mathrm{~m}$ (Gathmann and Tscharntke 2002), we selected this maximum distance to set the trap nests away from the forest edge.

The TNs were inspected once a month and those containing completed nests (nests with a plug) were removed and taken to the laboratory, where they were kept at room temperature until the emergence of individuals. All emerging individuals were removed, killed, and then pinned, labeled, and placed in the "Coleção de Abelhas e Vespas Solitárias do Departamento de Biologia da FFCLRP-USP." After the emergence of individuals, the nests were opened and the residual pollen content was collected from the nests for pollen analysis.

\subsection{Pollen analysis}

The residual pollen content from each nest was removed with small spatulas and placed in small vials containing $70 \%$ ethanol for at least $24 \mathrm{~h}$. Subsequently, the pollen samples were transferred to absolute acetic acid for $24 \mathrm{~h}$ prior to be acetolyzed according to the protocol of Erdtman (1960). A small cube of glycerin gelatin was used to remove a small amount of pollen from the samples and subsequently placed on microscopic slides. Pollen grains were identified, counted, and photographed under a light microscope (DM4000B, Leica, Wetzlar, Germany). The quantitative analysis was performed counting randomly 400 pollen grains of each nest sample (Vergeron 1964). The identification of pollen grains was performed using the palynological reference collection of LEEAV, "Laboratório de Ecologia e Evolução de Abelhas e Vespas" of the FFCLRP, University of São Paulo. The plant names cited herein followed The Plant List (2013).

In order to determine if the pollen grains found within the samples were obtained deliberately or picked up while bees were taking nectar or floral oils, the following characteristics were considered: the relative frequency of occurrence at the slides, the floral morphology and the available floral resources provided by the plant species, the literature data regarding the plants visited by the bee species sampled at CES, and their collection behavior on flowers. Also, it was checked if Coffea arabica pollen grains were identified in the samples from all nests collected.

\subsection{Diet breadth and network analysis}

To characterize the diet breadth of the community, two diversity indices were calculated for each bee species: richness, which shows the total number of each pollen type that was observed for each bee species, and Pielou's evenness, which indicates if the pollen types were explored in a uniform way $(=1)$ or not $(=0)$. 
The general trophic and temporal niche overlap degrees among all bee species in the community were calculated with the software TimeOverlap version 1.0 (Castro-Arellano et al. 2010) using the Pianka index (1973). Utilizing the Rosario algorithm, a null-model analysis based on 10,000 randomizations was performed to determine if the community overlap values found were different from that expected by chance using a two-tailed test and a significance level of 5\%. This algorithm creates randomizations of the original matrix and calculates the degree of niche overlap for each randomized matrix, comparing these values with the ones calculated for the original matrix. This index was estimated for the general community and for the set of species that nested in cold/dry months and for those species that nested in hot/wet months, using a matrix of relative abundance of pollen types observed (trophic) or nests sampled monthly (temporal) for each bee species.

Overlap degrees of trophic and temporal niches for each pair of bee species were estimated with the Schoener (1986) using the formula $\mathrm{NO}_{i h}=1$ $-1 / 2 \sum k\left|p_{i k}-p_{h k}\right|$ implemented in the package spaa 0.2.2 for $\mathrm{R}$ version 3.3.1 (R Core Team 2016), where $i$ and $h$ are the pair of bee species compared, and $p_{i k}$ and $p_{h k}$ are the relative abundance of each pollen type $k$ (trophic) or the total number of sampled nests in each month $k$ (temporal).

To describe the plant-pollinator interactions, a network was built for each season and for the general community from a matrix of relative abundance using the package bipartite (Dormann et al. 2009) for $\mathrm{R}$ version 3.3.1 ( $\mathrm{R}$ Core Team 2016). The degree of specialization in the diet was calculated in $\mathrm{R}$ version 3.3.1 (R Core Team 2016) measuring the $\mathrm{H}_{2}{ }^{\prime}$ index (Blüthgen et al. 2006) for the general community and for each season. This network-level index is derived from the Shannon diversity and measures specialization based on the deviation of interactions realized by a given species from that expected from a null distribution of interactions. Values of $\mathrm{H}_{2}{ }^{\prime}$ range between 0 (no specialization) and 1 (perfect specialization). A Monte Carlo procedure based on 1000 randomizations was performed using a null model (Patefield 1981), and the values calculated for each randomized matrix were compared with the value of the original matrix. To determine if the specialization degree found was different from that expected by chance, a two-tailed test was performed with a significance level of $5 \%$.

The nestedness of each layer and for the general network was calculated in the software NODF version 2.0 (Almeida-Neto and Ulrich, 2010) based on the binary metric NODF (Almeida-Neto et al. 2008). The significance of this index was estimated with a Monte Carlo procedure in which 1000 random matrices were generated using a null model (Gotelli 2000; Ulrich and Gotelli 2007). Nestedness is an ecological pattern characterized by asymmetrical interactions when specialist species interact with a subset of those of the generalist (Bascompte et al. 2003). Furthermore, high values of nestedness can be related to great stability in mutualistic networks (Thébault and Fontaine 2010).

\subsection{Coffee trees and floral visitors}

During the flowering period of $C$. arabica, from the end of October 2011 until the beginning of November, floral visitors were monitored, collected, killed, and deposited as voucher specimens in the "Coleção de Abelhas e Vespas Solitárias do Departamento de Biologia da FFCLRP-USP."

\section{RESULTS}

\subsection{Bee diversity}

A total of 12 bee species belonging to three families was sampled from August 2011 to July 2012 (Table I). The majority of nests belonged to Tetrapedia diversipes Klug (Apidae), which represented $68.3 \%$ of all sampled nests in the studied period. Because of the discrepancy between the total sampled nests of this species (200) when compared to the second most sampled species, i.e., Tetrapedia aff. peckoltii Friese (35), only five nests per month of $T$. diversipes from October 2011 to July 2012 were analyzed for pollen, totaling 50 separate nests. All nests of all other bee species had their residual pollen analyzed. Nests of $T$. diversipes were constructed in all areas, i.e., the forest edge, $250 \mathrm{~m}$, and $500 \mathrm{~m}$ 


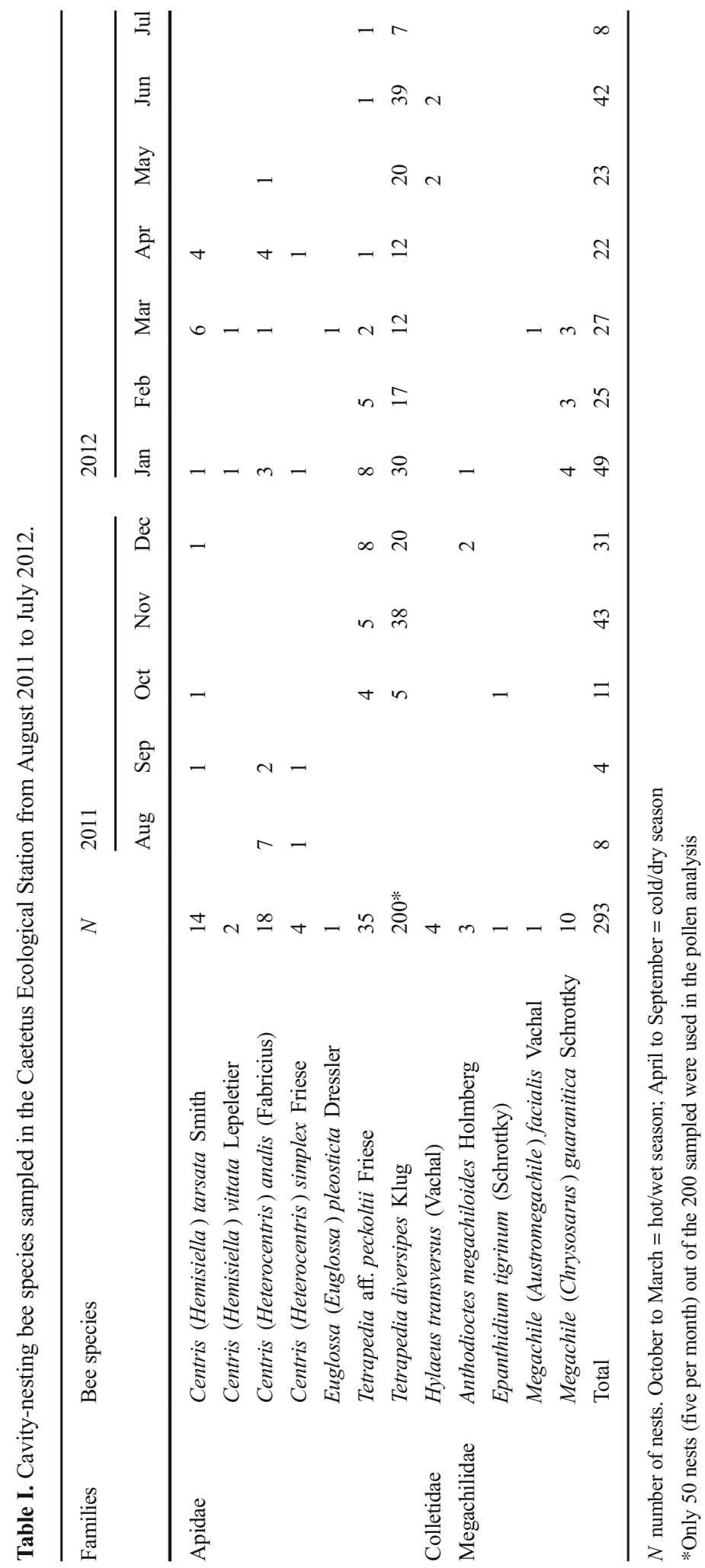


away from the forest edge. The species Tetrapedia aff. peckoltii, Centris analis, Centris vittata Lepeletier (Apidae), and Epanthidium tigrinum (Schrottky) (Megachilidae) nested only at the forest edge. Nests of Anthodioctes megachiloides Holmberg and Megachile facialis Vachal (Megachilidae) were only sampled $500 \mathrm{~m}$ away from the edge while nests of Euglossa pleosticta Dressler (Apidae) and Hylaeus transversus (Vachal) (Colletidae) only occurred $250 \mathrm{~m}$ away from the forest edge. Nests of Centris simplex Friese and Megachile guaranitica Schrottky were constructed only within the forest, $250 \mathrm{~m}$ and $500 \mathrm{~m}$ away from the edge, and Centris tarsata nests were built predominantly at the edge (13 nests), with only one nest recorded $250 \mathrm{~m}$ away from the forest edge.

Most of the species nested during the wet/hot season, between October and March, and $H$. transversus was the only species that built nests exclusively during the dry/cold season (Table I). The temporal niche analysis did not show overlap among the bee populations (Table II), but similar nesting phenologies were observed for closely related species, i.e., the two Tetrapedia species $\left(\mathrm{NO}_{\mathrm{ih}}=0.65\right)$ and the two Centris (Heterocentris) species $\left(\mathrm{NO}_{\mathrm{ih}}=0.75\right)$ (Table $\mathrm{S} 2$ - Appendix).

\subsection{Floral sources}

Sixty-three pollen types from 16 botanical families were identified in the 293 samples. Some of the most abundant pollen types found in the samples are displayed in Fig. 1. The two Tetrapedia spp. were the most commonly sampled of all bees species in the present study and presented the highest pollen type richness with 31 pollen types in nests of $T$. aff. peckoltii and 27 from $T$. diversipes samples. By contrast, rare species (three to one nest) such as E. pleosticta, H. transversus, and M. facialis collected floral resources from a single plant species each (Table III).

The two Centris (Heterocentris) spp. used Malpighiaceae species as both pollen and oil sources. Females of the two species belonging to the subgenus $C$. (Hemisiella) Moure, in turn, collected pollen from plant species with poricidal anthers like Solanum spp. (Solanaceae) and Senna sp. (Fabaceae) while Malpighiaceae plants served as oil sources. Pereskia grandifolia Haw. (Cactaceae) was the most important pollen source for both Tetrapedia spp., but in some nests of $T$. diversipes, pollen grains belonging to other plant species of three families were also prevalent.

Coffea arabica pollen grains were not identified in any of the samples removed from the nests of the trap-nesting bee species studied herein. Moreover, no specimen belonging to these bee species were observed on coffee tree flowers.

A nested pattern was observed for the networks built (Figures 2, S1 - Appendix) with a lower nestedness degree in the network of the cold/dry season (Table II). The community showed levels of specialization higher than that expected by chance for both seasons and for the general sampled period, with values of trophic and temporal niche overlap among

Table II. Interaction network and niche overlap (trophic and temporal) metrics calculated for the bee community and their floral sources at the Caetetus Ecological Station, SP, Brazil.

\begin{tabular}{|c|c|c|c|c|}
\hline & \multicolumn{2}{|c|}{ Interaction network } & \multirow{2}{*}{$\begin{array}{l}\text { Trophic niche overlap } \\
\text { Pianka }\end{array}$} & \multirow{2}{*}{$\begin{array}{l}\text { Temporal niche overlap } \\
\text { Pianka }\end{array}$} \\
\hline & NODF & $\mathrm{H}_{2}{ }^{\prime}$ & & \\
\hline Cold/dry season & $8.77 * *$ & $0.77 *$ & $0.14^{\mathrm{NS}}$ & $0.4^{\mathrm{NS}}$ \\
\hline Hot/wet season & $21.93 * *$ & $0.88^{*}$ & $0.06^{\mathrm{NS}}$ & $0.42^{\mathrm{NS}}$ \\
\hline General community & $28.49 * *$ & $0.92 *$ & $0.04^{\mathrm{NS}}$ & $0.28^{\mathrm{NS}}$ \\
\hline
\end{tabular}

For Pianka and $\mathrm{H}_{2}{ }^{\prime}$, *values significantly higher than that expected by a null distribution, ${ }^{\mathrm{NS}}$ values not different from that expect by null distribution, both for a $p<0.05$. For NODF, **values significantly different than that expected by a null distribution. The general community comprised all the sampled period 

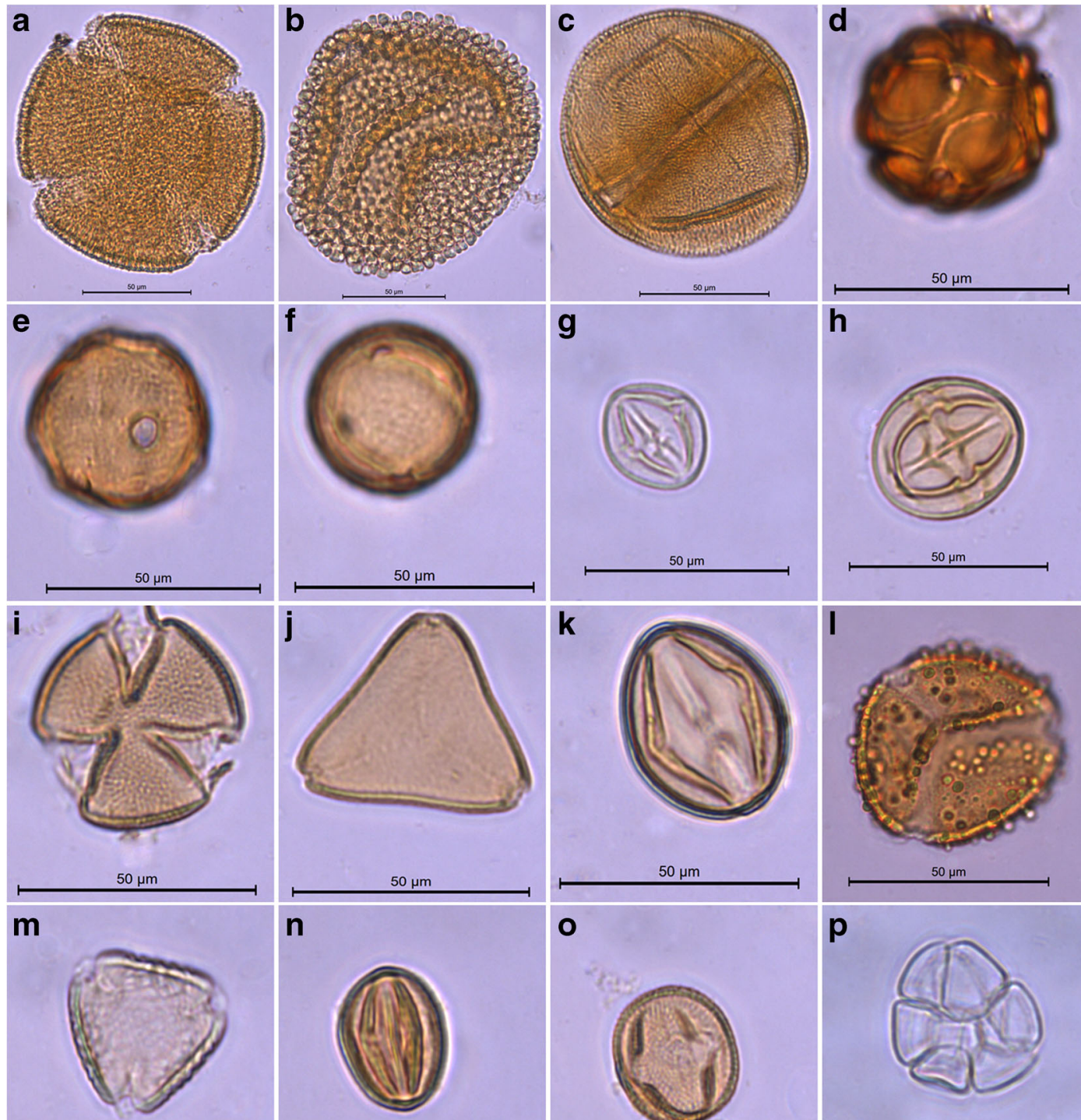

$50 \mu \mathrm{m}$
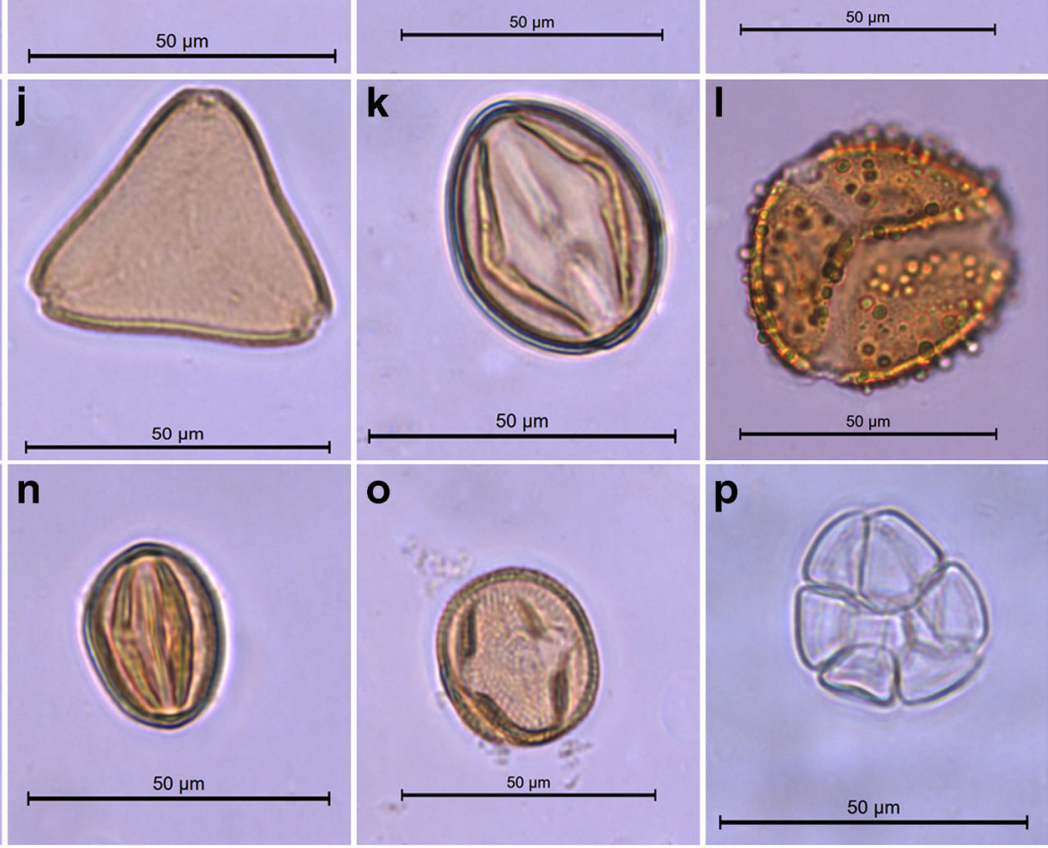

Figure 1. Some of the pollen types identified in the samples. a Pereskia grandifolia; b Croton floribundus; c Dalechampia pentaphylla; d Mascagnia cordifolia; e Heteropterys intermedia; f Niedenzuella acutifolia; $\mathbf{g}$ Solanum cf. mauritianum; h Solanum sp.; i Fridericia sp.; j Serjania laruotteana; k Senna sp.; I Bauhinia microstachya $; \mathbf{m}$ type Cajanus $; \mathbf{n}$ type Lonchocarpus; $\mathbf{0}$ Centrolobium tomentosum ; p Piptadenia gonoacantha .

populations not different from that expected by chance (Table II). Among species, the diet overlap was higher in congeneric species, the two Tetrapedia species $\left(\mathrm{NO}_{\mathrm{ih}}=0.82\right)$ and the two Centris (Heterocentris) species $\left(\mathrm{NO}_{\mathrm{ih}}=\right.$ 0.61) (Table S2 - Appendix).

\section{DISCUSSION}

Our analyses revealed a low trophic niche overlap among the bees within the trap-nesting community sampled in CES with similar use of floral source species by related taxa, i.e., within the same 
Table III. Diversity indices (Richness and Pielou's evenness) for each bee species sampled from August 2011 to July 2012 at the Caetetus Ecological Station, SP, Brazil.

\begin{tabular}{lll}
\hline Bee species & Richness & Pielou \\
\hline Tetrapedia aff. peckoltii & 31 & 0.26 \\
Tetrapedia diversipes & 27 & 0.39 \\
Centris tarsata & 15 & 0.58 \\
Centris analis & 14 & 0.54 \\
Megachile guaranitica & 9 & 0.07 \\
Centris simplex & 8 & 0.54 \\
Centris vittata & 6 & 0.34 \\
Epanthidium tigrinum & 4 & 0.36 \\
Anthodioctes megachiloides & 2 & 0.12 \\
Euglossa pleosticta & 1 & - \\
Hylaeus transversus & 1 & - \\
Megachile facialis & 1 & - \\
\hline
\end{tabular}

genus (Tetrapedia spp.) and in one case also subgenus (Centris (Heterocentris) spp.). Few plant species were used as pollen sources, and the species richness of the bee larval food was composed mostly by plant species that acted as nectar sources. Consequently, the studied community was composed of specialized populations. However, it is important to emphasize that given the lack of replications in the present study, our results may be restricted to the forest fragment studied herein. In spite of being immersed in an altered matrix of agricultural lands with a high density of invasive grasses throughout its surroundings (Melo et al. 2007), the large forest fragment in CES hosts a highly complex and species-rich flora (Durigan et al. 2000; Melo et al. 2007; Udulutsch et al. 2010), which provides a broad range of floral resources to the bees and also different nesting substrates such as dead wood and hollow twigs (Krombein 1967) for the cavity-nesting species. In addition, the fact that the region is located in a transitional area between two biodiversity hotspots, i.e., Atlantic Rainforest and Cerrado ecosystems (Myers et al. 2000), may explain the high species richness of some groups such as anurans (Brassaloti et al. 2010), birds (Cavarzere et al. 2009), bats (Pedro et al. 2001), and also cavitynesting wasps and bees (Rocha-Filho et al. 2017).
The most sampled bee species nested primarily at the forest edge, an environment in which the sunlight exposure is higher and ruderal plant species are prevalent (Tabarelli et al. 1999). As several weed species exhibit a high frequency of flowering (Grime 1979), thereby serving as important sources of pollen and nectar to nesting females, it is expected that more nests should be observed at the edge. Likewise, the abundance of trap-nesting bees and wasps was consistently lower in old-growth forests compared to young, more open sites in subtropical China possibly because the conditions in older forest stands may be less favorable for those thermophilic hymenopterans (Staab et al. 2016).

Despite the high availability of floral resources provided by the intense flowering of coffee trees, bees foraged on flowers of native plant species from the forest fragment and its surroundings and females use these floral resources for brood cell provisioning. Focal observations performed by Rocha-Filho and Garófalo (2016) on C. arabica flowers in the same study site recorded mostly workers of stingless bee species and Apis mellifera L. as floral visitors, a result that was also documented by other authors in Neotropical ecosystems (Ricketts et al. 2004; Veddeler et al. 2008; Vergara and Badano 2009).

Trophic niche overlap was found for the two Tetrapedia species and might be related to the high temporal overlap in nesting activities and to pollen grain features such as the grain size. Studies on the residual pollen content from nests of T. diversipes in different ecosystems showed that unrelated plant species of Dalechampia L. (Euphorbiaceae), Ludwigia L. (Onagraceae), and Pereskia Mill. (Cactaceae), all of them characterized by large pollen grains, are known as pollen sources (Menezes et al. 2012; Lyra-Neves et al. 2014; Rocha-Filho and Garófalo 2016). Additionally, the main source of pollen for the two Tetrapedia species, Pereskia grandifolia Haw., bloomed throughout all the year (Rocha-Filho and Garófalo 2016) and was located at the forest edge, where most of $T$. diversipes nests and all nests of $T$. aff. peckoltii were observed. In spite of collecting pollen from plant species belonging to four families, most of $T$. diversipes nests were provisioned with pollen from $P$. grandifolia, 


\section{Cold/Dry Season}

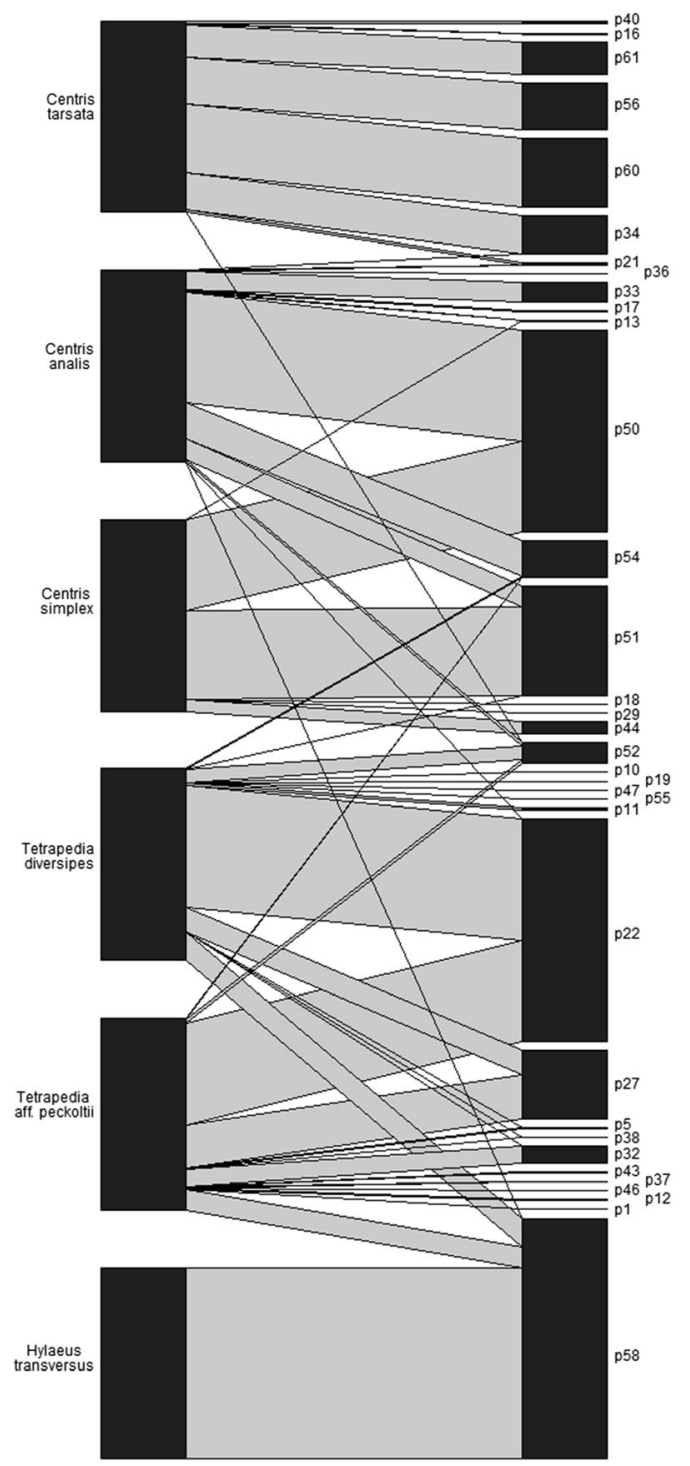

Hot/Wet Season

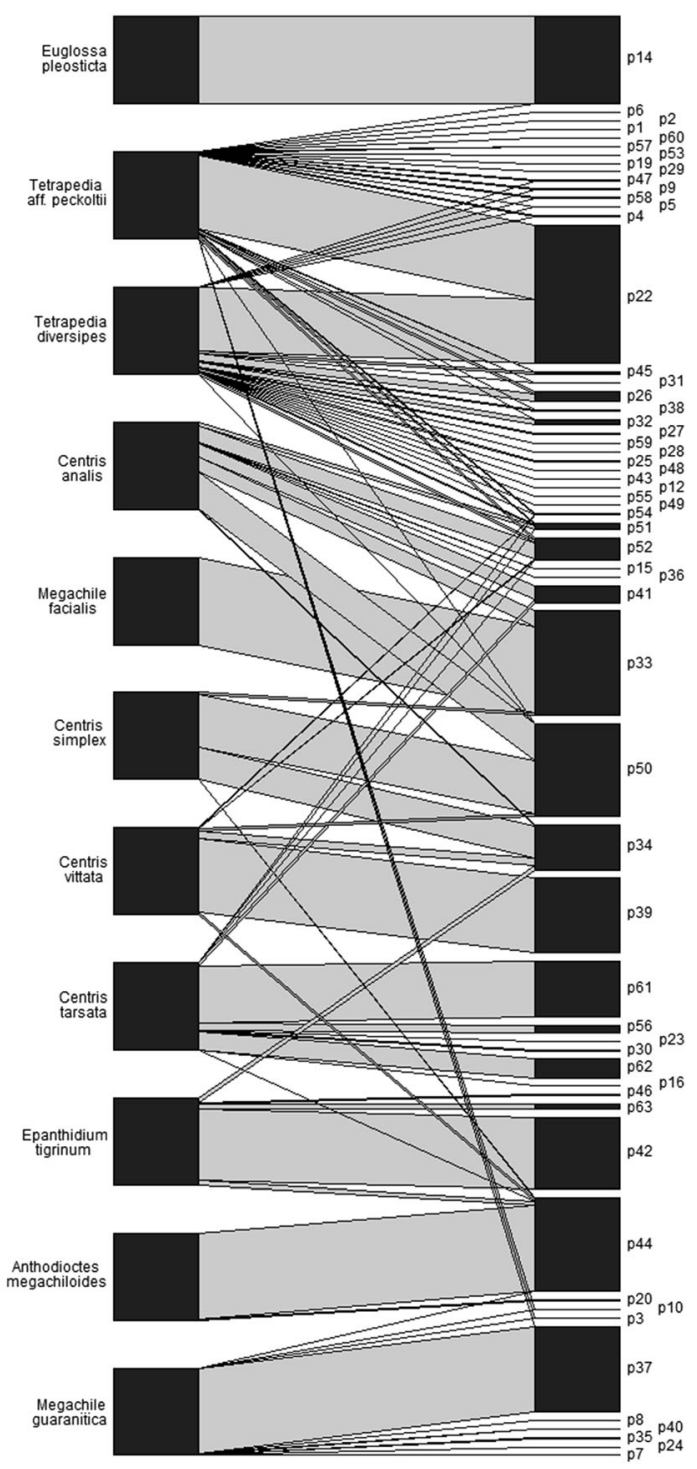

Figure 2. Weighted multilayer networks of the interaction between bee species and their floral sources at the Caetetus Ecological Station, SP, Brazil, during the cold/dry (network on the left) and hot/wet seasons (network on the right). Line thickness (interaction) represents the relative proportion of each pollen type collected be each bee species. Pollen types' codes are displayed in Table S1 (Appendix).

corroborating previous information on bee foraging since even generalist species have distinct preferences for some floral sources (Kleijn and Raemakers 2008).

Likewise, the two species of Centris (Heterocentris) Cockerell had high temporal overlap in nesting activities and used the same species of Malpighiaceae for both pollen and floral oil collection. Malpighiaceae species seem to be the most important pollen sources of Centris analis (Dórea et al. 2010; Santos et al. 2013; Rabelo et al. 2014) and Centris terminata Smith 
(Lima et al. 2017). By contrast, species of $C$. (Hemisiella ) Moure, as demonstrated in the present study, used plant species with poricidal anthers as pollen sources in brood provisioning while Malpighiaceae species are visited for the purpose of gathering floral oils (Dórea et al. 2009, 2013; Cruz et al. 2015).

As expected in mutualistic interaction networks (Bascompte et al. 2003), a nested pattern was observed in the CES. Other studies carried out in different ecosystems on bee-plant networks have also observed a nested structure (Dupont et al. 2003; Alarcón et al. 2008; Bosch et al. 2009; Santos et al. 2010; Chacoff et al. 2012; Mello et al. 2013; Aidar et al. 2015). Nonetheless, the nestedness degrees estimated for the bee community studied herein varied between the seasons. The nested pattern of the network observed for the hot/wet season could be a result of the nectar sources sharing among the most abundant, generalist species sampled (Tetrapedia spp.) with some rare bee species that performed a specialized behavior in the network and the higher abundance of bee species' nests recorded during the season. On the other hand, during the cold/dry season, a lower abundance of nests was recorded and most of these sampled nests belonged to species that showed distinct floral preferences (Centris (Heterocentris) spp., Malpighiaceae; H. transversus, Sapindaceae; and $T$. diversipes, Cactaceae). The presence of rare "specialized" species that showed low levels of trophic niche overlap among themselves during both seasons must have contributed to the high degree of specialization observed in the diet of the studied community. Similarly, Ballantyne et al. (2017) observed high values of specialization in a plant-pollinator in a Mediterranean meadow, especially in a pollinator importance network, which is characterized by the product of visitation frequency and effectiveness. We stress that our findings indicating that some of the studied bee species exhibit specialist foraging behavior must be treated with caution as the use of specialized floral resources was documented from only a small number of nests. Additionally, studies demonstrated that females of Euglossa spp., E. pleosticta in particular, are pollen and nectar generalists (Rocha-Filho et al. 2012; Villanueva-Gutierrez et al. 2013). Therefore, the comparisons among the generalist and "specialist" bee species sampled herein may be speculative because while seven species had less than five nests each in total, females of the two Tetrapedia species constructed more than 30 nests each.

Different nestedness degrees were found at distinct times of year, being higher during the hot/wet season, a period of great nesting activities for most of the bee species sampled. The higher species richness during this period, as well as to the interspecific asymmetry in the abundance, can contribute to the formation of this pattern within the community since strength and frequency of interactions can be related to the abundance of species (Vázquez et al. 2007). On the other hand, the seasons showed similar specialization levels, since pollen sources were poorly shared independently of the time of year while nectar sources were the main resources shared among the studied bee species.

In conclusion, the data presented herein showed that the cavity-nesting bee species were not characterized by an overlap in their diets, suggesting the occurrence of food niche partitioning among them. The asymmetry in the period of nesting activities and floral preferences among the bee species were factors that might have contributed to the low niche overlap observed. Additionally, the results obtained in this study suggest that the community would respond negatively to environmental disturbance during the cold/dry season compared to the hot/wet season since richness and nestedness in mutualistic networks are ecological factors that contribute positively with the persistence and resilience of the community (Thébault and Fontaine, 2010).

\section{ACKNOWLEDGEMENTS}

The authors are grateful to "Fundação de Amparo à Pesquisa do Estado de São Paulo - FAPESP" and to "Conselho Nacional de Desenvolvimento Científico e Tecnológico - CNPq" for providing scholarships to the first (10/52531-1) and second authors (140159/2014-2), respectively, and to Gabriel Melo (UFPR) for identifying part of the bees. We also would like to thank Thomas Onuferko (York University) and the two anonymous reviewers for the critical reading and valuable comments that improved the manuscript. 


\section{AUTHORS' CONTRIBUTIONS}

All authors participated in the design and interpretation of the data. LCRF wrote the manuscript, collected bee nests and analyzed pollen samples. LCRF and DMO participated in the data analysis. DMO and CAG participated in the writing. All authors read and approved the final manuscript. Faible chevauchement de niche trophique entre espèces d'abeilles dans des nichoirs (Hymenoptera: Anthophila) dans un fragment de forêt semicaduque.

Faible chevauchement de niche trophique entre espèces d'abeilles dans des nichoirs (Hymenoptera: Anthophila) dans un fragment de forêt semi-caduque

Abeilles à cavités de nidification, alimentation, huile florale, nectar, pollen, populations spécialisées.

Niedrige trophischer Nischenüberlappung zwischen Bienenarten in Nisthilfen (Hymenoptera: Anthophila) in einem halb-laubabwerfenden Waldfragment.

Stängel-nistende Bienen, Nahrungsbreite, Blütenöl, Nektar, Pollen, spezialisierte Populationen

\section{REFERENCES}

Aguiar, C.M.L., Caramés, J., França, F., Melo, E. (2017). Exploitation of floral resources and niche overlap within an oil-collecting bee guild (Hymenoptera: Apidae) in a Neotropical savannah. Sociobiology 64 (1), 7884.

Aguiar, C.M.L., Santos, G.M.M., Martins, C.F., Presley, S.J. (2013). Trophic niche breadth and niche overlap in a guild of flower-visiting bees in a Brazilian dry forest. Apidologie 44 (2), 153-162.

Aidar, I.F., Bartelli, B.F., Nogueira-Ferreira, F.H. (2015). Network of bee-plant interactions and recognition of key species in Semideciduous Forest. Sociobiology 62 (4), 583-592.

Alarcón, R., Waser, N., Ollerton, J. (2008). Year-to-year variation in the topology of a plant-pollinator interaction network. Oikos 117 (12), 1796-1807.

Almeida-Neto, M., Guimarães, P., Guimarães, P.R., Lodola, R.D., Ulrich, W. (2008). A consistent metric for nestedness analysis in ecological systems: Reconciling concept and measurement. Oikos 117 (8), 12271239.

Almeida-Neto, M., Ulrich, W. (2010). A straightforward computational approach for quantifying nestedness using abundance data. Environ. Model. Softw. 26 (2), 173-178.

Andena, S.R., Santos, E.F., Noll, F.B. (2012). Taxonomic diversity, niche width and similarity in the use of plant resources by bees (Hymenoptera: Anthophila) in a cerrado area. J. Nat. Hist. 46 (27-28), 16631687.

Ballantyne, G., Baldock, K.C.R., Rendell, L., Willmer, P.G. (2017). Pollinator importance networks illustrate the crucial value of bees in a highly speciose plant community. Sci. Rep. 7, 8389.

Bartomeus, I., Bosch, J., Vilà, M. (2008). High invasive pollen transfer, yet low deposition on native stigmas in a Carpobrotus -invaded community. Ann. Bot. 102 (3), 417-424.

Bascompte, J., Jordano, P., Melián, C.J., Olesen, J.M. (2003). The nested assembly of plant-animal mutualistic networks. Proc. Natl Acad. Sci. USA. 100 (16), 9383-9387.

Bawa, K.S. (1990). Plant-pollinator interactions in tropical rain forests. Annu. Rev. Ecol. Syst. 21, 399-422.

Beckerman, A.P., Petchey, O.L., Warren, P.H. (2006). Foraging biology predicts food web complexity. PNAS 103 (37), 13745-13749.

Blüthgen, N., Menzel, F., Blüthgen, N. (2006). Measuring specialization in species interaction networks. BMC Ecol. 6, 1-12.

Bommarco, R., Biesmeijer, J.C., Meyer, B., Potts, S.G., Pöyry, J., Roberts, S.P.M., Steffan-Dewenter, I., Öckinger, E. (2010). Dispersal capacity and diet breadth modify the response of wild bees to habitat loss. Proc. R. Soc. B 277, 2075-2082.

Bosch, J., Martín González, A.M., Rodrigo, A., Navarro, D. (2009). Plant-pollinator networks: adding the pollinator's perspective. Ecol. Lett. 12 (5), 409-419.

Brassaloti, R.A., Rossa-Feres, D.C., Bertoluci, J. (2010). Anurofauna da Floresta Estacional Semidecidual da Estação Ecológica dos Caetetus, sudeste do Brasil. Biota Neotrop. 10 (1), 275-291.

Camillo, E., Garófalo, C.A., Serrano, J.C., Muccillo, G. (1995). Diversidade e abundância sazonal de abelhas e vespas solitárias em ninhos armadilhas (Hymenoptera: Apocrita, Aculeata). Rev. Bras. Entomol. 39 (2), 459-470.

Carman, K., Jenkins, D.G. (2016). Comparing diversity to flower-bee interaction networks reveals unsuccessful foraging of native bees in disturbed habitats. Biol. Conserv. 202 (2016), 110-118.

Castro-Arellano, I., Lacher, T. Jr., Willig, M.R., Rangel, T.F. (2010). Assessment of assemblage-wide temporal niche segregation using null models. Meth. Ecol. Evol. 1 (3), 311-318.

Cavarzere, V., Moraes, G.P., Donatelli, R.J. (2009). Avifauna da Estação Ecológica dos Caetetus, interior de São Paulo, Brasil. Pap. Avulsos Zool. 49 (35), 477-485.

Chacoff, N.P., Vázquez, D.P., Lomáscolo, S.B., Stevani, E.L., Dorado, J., Padrón, B. (2012). Evaluating 
sampling completeness in a desert plant-pollinator network. J. Anim. Ecol. 81 (1), 190-200.

Core Team R (2016). R: A language and environment for statistical computing. Version 3.3.1. Vienna: R Foundation for Statistical Computing. https://www.R-project.org/.

Cruz, A.P.A., Dórea, M.C., Lima, L.C.L. (2015). Pollen types used by Centris (Hemisiella) tarsata Smith (1874) (Hymenoptera, Apidae) in the provisioning of brood cells in an area of Caatinga. Acta Bot. Bras. 29 (2), 282-284.

Dorado, J., Vázquez, D.P., Stevani, E.L., Chacoff, N.P. (2011). Rareness and specialization in plant-pollinator networks. Ecology 92 (1), 19-25.

Dórea, M.C., Aguiar, C.M.L., Figueroa, L.H.F., Lima, L.C.L., Santos, F.A.R. (2010). Residual pollen in nest of Centris analis (Hymenoptera, Apidae, Centridini) na área of caatinga vegetation from Brazil. Oecol. Aust. 14 (1), 232-237.

Dórea, M.C., Aguiar, C.M.L., Figueroa, L.H.F., Lima, L.C.L., Santos, F.A.R. (2013). A study of pollen residues in nest of Centris trigonoides Lepeletier (Hymenoptera, Apidae, Centridini) in Caatinga vegetation, Brazil. Grana 52 (2), 122-128.

Dórea, M.C., Santos, F.A.R., Lima, L.C.L., Figueroa, L.H.R. (2009). Análise polínica do resíduo pósemergência de ninhos de Centris tarsata Smith (Hymenoptera: Apidae, Centridini). Neotrop. Entomol. 38 (2), 197-202.

Dormann, C.F., Fruend, J., Bluethgen, N., Gruber B. (2009). Indices, graphs and null models: analyzing bipartite ecological networks. Open. J. Ecol. 2, 7-24.

Dupont, Y.L., Hansen, D.M., Olesen, J.M. (2003). Structure of a plant-flower-visitor network in the highaltitude sub-alpine desert of Tenerife, Canary Islands. Ecography 26 (3), 301-310.

Durigan, G., Franco, G.A.D.C., Saito, M., Baitello, J.B. (2000). Estrutura e diversidade do componente arbóreo da floresta na Estação Ecológica dos Caetetus, Gália, SP. Rev. Bras. Bot. 23 (4), 371-383.

Erdtman, G. (1960). The acetolized method. A revised description. Svensk Bot. Tidskr. 54, 561-564.

Freitas, B.M., Paxton, R.J. (1998). A comparison of two pollinators: the introduced honey bee (Apis mellifera) and an indigenous bee (Centris tarsata) on cashew (Anacardium occidentale L.) in its native range of $\mathrm{Ne}$ Brazil. J. Appl. Ecol. 35 (1), 109-121.

Garibaldi, L.A., Steffan-Dewenter, I., Winfree, R., Aizen, M.A., Bommarco, R. et al. (2013). Wild pollinators enhance fruit set regardless of honey bee abundance. Science 339 (6127), 1608-1611.

Gathmann, A., Tscharntke, T. (2002). Foraging ranges of solitary bees. J. Anim. Ecol. 71 (5), 757-764.

Gotelli, N.J. (2000). Null model analysis of species cooccurrence patterns. Ecology 81 (9), 2606-2621.

Grime, J.P. (1979). Plant strategies and vegetation processes. Wiley, Chichester.

Hilgert-Moreira, S., Nascher, C., Callegari-Jacques, S., Blochtein, B. (2013). Pollen resources and trophic niche breadth of Apis mellifera and Melipona obscurior (Hymenoptera, Apidae) in a subtropical climate in the Atlantic rain forest of southern Brazil. Apidologie 45 (1), 129-141.

Junqueira, C.N., Hogendoorn, K., Augusto, S.C. (2012). The use of trap-nests to manage carpenter bees (Hymenoptera: Apidae: Xylocopini), pollinators of passion fruit (Passifloraceae: Passiflora edulis f. flavicarpa). Ann. Entomol. Soc. Am. 105 (6), 884-889.

Kleijn, D., Raemakers, I. (2008). A retrospective analysis of pollen host plant use by stable and declining bumblebee species. Ecology 89 (7), 1811-1823.

Klein, A.-M., Vaissière, B.E., Cane, J.H., SteffanDewenter, I., Cunningham, S.A., Kremen, C., Tscharntke, T. (2007). Importance of pollinators in changing landscapes for world crops. Proc. R. Soc. B 274 (1608), 303-313.

Kratochwil, A., Beil, M., Schwabe, A. (2009). Complex structure of pollinator-plant interaction-webs: random, nested, with gradients or modules? Apidologie 40 (6), 634-650.

Krombein, K.V. (1967). Trap nesting wasps and bees. Life histories, nests and associates. Smithsonian Institution Press, Washington.

Lima, R., Ferreira-Caliman, M.J., Dórea, M.C., Garcia, C.T., Santos, F.A.R., Oliveira, F.F., Garófalo, C.A. (2017). Floral resource partitioning between Centris (Heterocentris ) analis (Fabricius, 1804) and Centris (Heterocentris ) terminata Smith, 1874 (Hymenoptera, Apidae, Centridini), in an urban fragment of the Atlantic Forest. Sociobiology 64 (3), 292-300.

Lopezaraiza-Mikel, M.E., Hayes, R.B., Whalley, M.R., Memmott, J. (2007). The impact of an alien plant on a native plant-pollinator network: an experimental approach. Ecol. Lett. 10 (7), 539-550.

Lyra-Neves, C.M., Carvalho, C.A.L., Machado, C.S., Aguiar, C.M.L., Sousa, F.S.M. (2014). Pollen consumed by the solitary bee Tetrapedia diversipes (Apidae: Tetrapediini) in a tropical agroecosystem. Grana 53 (4), 302-308.

Mello, M.A.R., Bezerra, E.L.S., Machado, I.C. (2013). Functional roles of Centridini oil bees and Malpighiaceae oil flowers in biome-wide pollination networks. Biotropica 45 (1), 45-53.

Melo, A.C.G., Durigan, G., Gorenstein, M.R. (2007). Efeito do fogo sobre o banco de sementes em faixa de borda de Floresta Estacional Semidecidual, SP, Brasil. Acta Bot. Bras. 21 (4), 927-934.

Menezes, G.B., Gonçalves-Esteves, V., Bastos, E.M.A.F., Augusto, S.C., Gaglianone, M.C. (2012). Nesting and use of pollen resources by Tetrapedia diversipes Klug (Apidae) in Atlantic Forest areas (Rio de Janeiro, Brazil) in different stages of regeneration. Rev. Bras. Entomol. 56 (1), 86-94.

Michener, C.D. (2007). The bees of the world, 2nd edition. Johns Hopkins University Press, Baltimore.

Myers, N., Mittermeier, R.A., Mittermeier, C.G., Fonseca, G.A.B., Kent, J. (2000). Biodiversity hotspots for conservation priorities. Nature 403, 853-845.

Oliveira, R., Schlindwein, C. (2009). Searching for a manageable pollinator for Acerola orchards: the solitary 
oil-collecting bee Centris analis (Hymenoptera: Apidae: Centridini). J. Econ. Entomol. 102 (1), 265273.

Ollerton, J., Winfree, R., Tarrant, S. (2011). How many flowering plants are pollinated by animals? Oikos 120 (3), 321-326.

Patefield, W.M. (1981) Algorithm AS159. An efficient method of generating $\mathrm{r} \times \mathrm{c}$ tables with given row and column totals. Appl. Statist. 30 (1), 91-97.

Pedro, W.A., Passos, F.C., Lim, B.K. (2001). Morcegos (Chiroptera; Mammalia) da Estação Ecológica de Caetetus, Estado de São Paulo. Chiroptera Neotrop. 7 (1-2), 136-140.

Potts, S.G., Biesmeijer, J.C., Kremen, C., Neumann, P., Schweiger, O., Kunin, W.E. (2010). Global pollinator declines: trends, impacts and drivers. Trends Ecol. Evol. 25 (6), 345-353.

Quiróz-Garcia, D.L., Martinez-Hernandez, E., PalaciosChavez, R., Galindo-Miranda, N.E. (2001). Nest provisions and pollen foraging in three species of solitary bees (Hymenoptera: Apidae) from Jalisco, Mexico. J. Kansas Entomol. Soc. 74 (2), 61-69.

Rabelo, L.S., Vilhena, A.M.G.F., Bastos, E.M.A.F., Augusto, S.C. (2014). Differentiated use of pollen sources by two sympatric species of oil-collecting bees (Hymenoptera: Apidae). J. Nat. Hist. 48 (25-26), 1595-1609.

Ricketts, T.H., Daily, G.C., Ehrlich, P.R., Michener, C.D. (2004). Economic value of tropical forest to coffee production. Proc. Natl. Acad. Sci. USA 101 (34), 12579-12582.

Rocha-Filho, L.C., Garófalo, C.A. (2016). Natural history of Tetrapedia diversipes (Hymenoptera, Apidae) in an Atlantic semi-deciduous forest remnant surrounded by coffee crops, Coffea arabica (Rubiaceae). Ann. Entomol. Soc. Am. 109 (2), 183-197.

Rocha-Filho, L.C., Krug, C., Silva, C.I., Garófalo, C.A. (2012). Floral resources used by Euglossini bees (Hymenoptera: Apidae) in coastal ecosystems of the Atlantic forest. Psyche 2012, 1-13.

Rocha-Filho, L.C., Rabelo, L.S., Augusto, S.C., Garófalo, C.A. (2017). Cavity-nesting bees and wasps (Hymenoptera: Aculeata) in a semi-deciduous Atlantic forest fragment immersed in a matrix of agricultural land. J. Insect Conserv. 21 (4), 727-736.

Saito, M., Durigan, G., Baitello, J.B., Franco, G.A.D.C., Pastore, J.A., Aguiar, O.T., Nakata, H. (2004). Ocorrência de espécies vegetais em diferentes condições de habitat e etapas do processo sucessional na região de Assis, SP. Pesquisas em conservação e recuperação ambiental no Oeste Paulista: resultados da cooperação Brasil/Japão. Pesquisas em conservação e recuperação ambiental no Oeste Paulista: resultados da cooperação Brasil/Japão. 1st edition. Vol. 1. Bôas OV, Durigan D (orgs.). Páginas and Letras, São Paulo, SP, Brazil. http://iflorestal.sp.gov.br/files/2004/01/IF-C14. pdf.

Santos, R.M., Aguiar, C.M.L., Dórea, M.C., Almeida, G.F., Santos, F.A.R., Augusto, S.C. (2013). The larval provisions of the crop pollinator Centris analis : pollen spectrum and trophic niche breadth in an agroecosystem. Apidologie 44 (6), 630-641.

Santos, G.M.M., Aguiar, C.M.L., Mello, M.A.R. (2010). Flower-visiting guild associated with the Caatinga flora: trophic interaction networks formed by social bees and social wasps with plants. Apidologie 41 (4), 466475.

Schoener, T.W. (1986) Resource partitioning. In: Kikkawa, J., Anderson, D. J. (eds) Community Ecology - Pattern and Process. Blackwell Scientific Publications, Boston, pp 91-126.

Staab, M., Bruelheide, H., Durka, W., Michalski, S., Purschke, O., Zhu C.D., Klein, A.-M. (2016). Tree phylogenetic diversity promotes host-parasitoid interactions. Proc. R. Soc. B 283 (1834), 20160275.

Tabanez, M.F., Durigan, G., Keuroghlian, A., Barbosa, A.F., Freitas, C.A., et al. (2005). Plano de Manejo da Estação Ecológica dos Caetetus. IF Série Registro 29, $1-104 \mathrm{http}: / / \mathrm{s} 3$. a mazonaws.com/ WCSResources/file $20110822090807 \mathrm{mtabanez}$ PlanoManejoEstacaoEcologicaDosCaetetus_2004_ xOsP.pdf.

Tabarelli, M., Mantovani, W., Peres, C.A. (1999). Effects of habitat fragmentation on plant guild structure in the montane Atlantic forest of southeastern Brazil. Biol. Conserv. 91 (2-3), 119-127.

The Plant List. (2013). Version 1.1. http://www.theplantlist. org/.

Thébault, E., Fontaine, C. (2010). Stability of ecological communities and the architecture of mutualistic and trophic networks. Science 329 (5993), 853-856.

Udulutsch, R.G., Souza, V.C., Rodrigues, R.R., Dias, P. (2010). Composição florística e chaves de identificação para as lianas da Estação Ecológica dos Caetetus, estado de São Paulo, Brasil. Rodriguésia 61 (4), 715-730.

Ulrich, W., Gotelli, N.J. (2007). Null model analysis of species nestedness patterns. Ecology 88 (7), 1824 1831.

Vázquez, D.P., Melián, C.J., Williams, N.M., Blüthgen, N., Krasnov, B.R., Poulin, R. (2007). Species abundance and asymmetric interaction strength in ecological networks. Oikos 116 (7), 1120-1127.

Veddeler, D., Olschewski, R., Tscharntke, T., Klein, A.-M. (2008). The contribution of non-managed social bees to coffee production: new economic insights based on farm-scale yield data. Agroforest. Syst. 73 (2), 109-114.

Vergara, C.H., Badano, E.I. (2009). Pollinator diversity increases fruit production in Mexican coffee plantations: the importance of rustic management systems. Agric. Ecosyst. Environ. 129 (1-3), 117-123.

Vergeron, P. (1964). Interprétation statistique des résultats en matière d'analyse pollinique des miels. Ann. Abeille 7 (4), 349-364.

Vilhena, A.M.G.F., Rabelo, L.S., Bastos, E.M.A.F., Augusto, S.C. (2012). Acerola pollinators in the savannah of Central Brazil: temporal variations in oilcollecting bee richness and a mutualistic network. Apidologie 43 (1), 51-62. 
Villanueva-Gutierrez, R., Quezada-Euan, J., Eltz, T. (2013). Pollen diets of two sibling orchid bee species, Euglossa, in Yucatán, southern Mexico. Apidologie 44 (4), 440-446.

Winemiller, K.O., Fitzgerald, D.B., Bower, L.M., Pianka, E.R. (2015). Functional traits, convergent evolution, and periodic tables of niches. Ecol. Lett. 18 (8), 737751.
Wood, T.J., Holland, J.M., Goulson, D. (2016). Diet characterisation of solitary bees on farmland: dietary specialisation predicts rarity. Biodivers. Conserv. 25 (13), 2655-2671.

Zuefle, M.E., Brown, W.P., Tallamy, D.W. (2008). Effects of nonnative plants on native insect community of Delaware. Biol. Invasions 10, 1159-1169. 